\title{
Öğrencilerin Değerlendirmeleriyle Çalg1 Çalışma Motivasyonlarını Olumlu ve Olumsuz Etkileyen Öğretmen Özellikleri
}

\section{Teachers' Features that Have Positive and Negative Influences on Instrument Training Motivation through The Students' Evaluation}

\section{Serpil Umuzdaş}

Doç. Dr., Tokat Gaziosmanpaşa Üniversitesi, Devlet Konservatuvarı

email: sumuzdas@hotmail.com (DORCID ID: https://orcid.org/0000-0002-6013-2406

Mihriban Yağız

Yüksek Lisans Öğrencisi., Tokat Gaziosmanpaşa Üniversitesi, Devlet Konservatuvarı email: yagizmihriban08@gmail.com (DORCID ID: https://orcid.org/0000-0002-4185-2192

\begin{abstract}
$\checkmark$ iThenticate' $\mathrm{Bu}$ makale bilimsel etik ve kurallara uygun hazırlanmış ve intihal incelemesinden geçirilmiştir. Etik kurul onayı gerektirmemektedir.

Atıf (APA 6)/To cite this article

Umuzdaș, S., \& Yağız, M. (2020). Öğrencilerin değerlendirmeleriyle çalgı çalıșma motivasyonlarını olumlu ve olumsuz etkileyen öğretmen özellikleri. Atatürk Üniversitesi Güzel Sanatlar Enstitüsü Dergisi, 26(45), 546-557. doi: https://doi.org/10.35247/ataunigsed.748422
\end{abstract}

Makale Gönderim Tarihi/Received: 05/06/2020

Makale Kabul Tarihi/Accepted: 21/09/2020

Makale Yayın Tarihi/Published: 22/10/2020

Research Article/Araștırma Makalesi

Öz

Bu çalışmada, çalgı eğitimi almakta olan öğrencilerin öğretmen davranışlarını motivasyonel bağlamdaki değerlendirmelerinin betimlenmesi amaçlanmıştır. Bu amaçla veriler öğrencilerden üç açık uçlu soru ile toplanmıștır. Çalıșma, nitel betimsel tarama modelindedir. Calışma grubunu Tokat Gaziosmanpaşa ve Niğde Ömer Halisdemir Üniversiteleri bünyesindeki müzik öğretmenliği anabilim dalı öğrencileri olușturmuștur. Araştırma verileri betimsel analiz yöntemleri kullanılarak çözümlenmiştir. Öğrencilerin değerlendirmelerine göre; çalg1 çalıșma motivasyonlarını olumlu etkileyen öğretmen özellikleri; enerjik, saygılı, ilgili, sabırlı ve esprili olması, hedef ve kazanımlar hakkında bilgilendirme yapması, iyi bir öğrenci olması, öğrencinin yeteneğini fark etmesini sağlaması, dönüt vermesi, kendini mesleki olarak yenilemesi, iyi müzisyen olması, kendi çalgı çalışma motivasyonunun yüksek olması, derse hazırlıklı gelmesi, destek vermesi, verdiği ödevi tanıtıp çözümletmesi, parça seçerken öğrencinin fikrini alması, iyi bir dinleyici olması, derste teorik bilgiye de yer vermesi, öğrenciyle birlikte çalması, çok nota kaynağının olmasıdır. Öğrencilerin çalgı çalıșma motivasyonlarını olumsuz etkileyen öğretmen özellikleri ise; soğuk davranışları, kendi olumsuz duygu ve durumlarını öğrenciye yansıtması, ilgisizliği, öğrenci hata yaptığında aşağılaması/küçümsemesi, çok ödev vermesi, düzeyin altında ya da üstünde ödev vermesi, çalınamayan yerleri anlatmak yerine yeni ödev vermesi, dersi aksatması, dersi uzatmasıdır. Öğrenciler, çalg1 öğretmenlerinden; değerlere sahip olmasını, yapıcı eleștirilerde bulunmasını ve anlayıșlı olmasını, öğretmeninin derste kendisiyle birlikte çalmasını, öğrencinin düzeyini bilmesini, etkili çalmasını, ayrıntılı çalıștırmasını, dinletiler düzenlemesini ve kendini yenilemesini beklemektedir.

Anahtar kelimeler: Çalgı Eğitimi, Öğretmen Özellikleri, Öğrenci Motivasyonu

\begin{abstract}
The aim of this study is to describe the students' evaluation of teacher behaviors in the motivational context. For this purpose, data were collected from students with three open-ended questions. The study is in a qualitative descriptive scanning model. The study group was composed of students in the department of music teaching at Tokat Gaziosmanpaşa and Niğde Ömer Halisdemir Universities. Research data were analyzed using descriptive analysis methods. According to the students' evaluations, teacher characteristics that positively affect instrument motivation are energetic, respectful, concerned, patient, humorous, informing about goals and achievements, being a good student, making the student realize his talent, giving feedback, renewing himself professionally, being a good musician, having a high motivation to study his instrument, being prepared for the lesson, giving support, introducing and analyzing the homework he gave, getting the idea of the student when choosing a track, being a good listener, also including theoretical information in the lesson, playing with the student, and having a lot of notes. Teacher characteristics that negatively affect students' instrument motivation are cold behavior, reflecting their negative feelings and situations to the student, indifference, humiliation/belittling when the student makes a mistake, giving too much homework, giving homework below or above the level, giving new homework instead of telling the places that cannot be stolen, disrupting the lesson, extending the lesson. Students expect their instrument teachers to have values, to make constructive criticism and to be understanding, to play with him in the lesson, to know the level of the student, to play effectively, to train in detail, to organize concerts and to renew himself.
\end{abstract}

Keywords: Instrument Education, Teacher Characteristics, Student Motivation

\section{Giriș}

Müzik bir uzmanlık dalıdır ve bu uzmanlığa sahip olmak için genellikle en az bir çalgıda yüksek performansa sahip olmak gerekir. Bir çalgıyı uzmanlık alanı olarak pratik ediyorsanız bazı zamanlarda müzikten amatör bir çalgıcı kadar zevk alamayabilirsiniz. Zira iyi bir performans için yapılan sürekli pratik yapmak, müzisyenin diğer bazı etkinliklerini oldukça kısıtlayabilir. Ayrıca profesyonel gitarist olmak, hekim olup gitar çalmaktan daha fazla 
veya ayrıntılı çalgı çalışma sorumluluğu gerektirebilir. Profesyonel anlamda çalgı çalışmak, "çalgıda teknik ve müzikal becerilerin gelişimi amacıyla, eksikliklerinin giderilmesine yönelik çalışmalar yapmaktır. Çalışılan eserin amacını ve gereğini bilmek, o amaca ulaşmada ilk koşuldur.” (Umuzdaş, 2013).

Araştırmalar; üniversite düzeyinde müzik eğitimi veren, özellikle konservatuarlar gibi klasik performansa dayalı olarak derecelendirilen programlarda; müzik sınıfı ortamının genellikle öğrenci motivasyonu için en uygun yer olmadığını göstermektedir. Sınıftaki öğretim genellikle zorlu, yönlendirici ve kontrol edici bir tarzı benimser (Gaunt, 2011, s. 162). Burada öğretmenler genellikle az girdi ile konuşarak teknik taleplerde bulunurlar (Young, Burwell ve Pickup, 2003, s. 146).

Öğrenciler, mesleki amaçlarla müzik eğitimi almaya karar verdiklerinden, müzik eğitim programına belli bir motivasyonla kayıt yaptırmışlardır. Ancak motivasyonun artışı ya da devamlılığı için öğretmenin desteği gerekebilir. Zira yukarıda da bahsedildiği gibi müzikte öğrenciyi zorlu görevler beklemektedir. Evans (2015, s. 71) öğrencinin çalgı eğitimindeki motivasyonunun, hangi amaçla çalgı öğrenmek istediği ve öğrenme sürecindeki problemleri nasıl karşıladığı ile ilgili olduğunu belirtir. Pintrich ve Schunk (2002) motivasyonu, bireyin bir işi başarmadaki çabası, azmi ve beceri yönetimi olarak tanımlamaktadır. Motivasyon, bireyin gelişimini destekler ve potansiyelini etkili şekilde kullanmasını sağlar (Eggen ve Kauchak, 2001, s. 339).

Motive öğrencilerin; derse hazırlık yapmaya özen gösterdikleri, derse ilgi ve katılım gösterdikleri, çabalı, azimli ve istikrarlı oldukları görülmektedir (Dilekmen ve Ada, 2005, s. 114). Böylece motive öğrencilerin daha başarılı oldukları anlaşılmaktadır (Amrai, Motlagh, Zalani, ve Parhon, 2011, s. 400; Caruth, 2018, s. 19, Francis ve diğerleri, 2004; Goodman ve diğerleri, 2011; Gorham ve Milette, 1997; Maric ve Sakac, 2014; Margolis ve Mccabe, 2004; Murphy ve Alexender, 2000; Kaufmann ve Humsan, 2004; Orhan Özen, 2017; Özgüngör ve Kapıkıran, 2008; Yazıcı ve Altun, 2013). Motivasyon, kaynağını bireyin kendisinden veya çevresinden alır, bu algılarına dayanan iç ve dış güçler davranışın başlamasına ve sürmesine yaramaktadır (Vallerand ve Thill, 1993). Slavin, 2013; Maulana ve diğerleri (2016, s. 118)'e göre öğretmenin davranışları öğrenci motivasyonuna etki edebilen etkenlerden biridir.

Wang ve Eccles (2013, s. 15)'e göre eğitimcilerin ve araştırmacıların, öğrenmenin sağlanamaması sonucunda devamsızlık veya okulu bırakma ihtimallerini önlemek için, motivasyonun nasıl sağlandığı ya da sürdürüleceği konusunda farkındalık geliştirmeleri gerekir. Destek gören öğrenci okula gelir, görevler alır ve başarılı olmaya çalışır. Aksi halde, öğretmenlerle olan ilişkilerini, yüksek düzeyde olumsuz olarak algılayan öğrencilerin motivasyonu düşerek başarısız olabilir (Passini, Molinari ve Speltini, 2015, s. 548).

Öğretmenler, öğrencilerin derse daha istekli ve motive bir şekilde katılarak, dersin daha aktif ve verimli geçmesi sağlayabilir. Sadece kendi alanına hâkim olmak, iyi öğretmenlik için yeterli görülmemektedir. Bunun dışında öğretmen; genel kültürü zengin, güncel gelişmeleri takip eden, gelişimsel süreçler bağlamında farklı yaşlara özgü özellikleri bilerek etkili iletişim sağlayabilir nitelikte olmalıdır. Bu niteliklerden yoksun yahut gereken düzeyde sahip olmayan bir müzik öğretmeni, mesleğinin gerekliliklerini yerine getiremeyeceği gibi öğrencilerin derse olan ilgilerinin ve sevgilerinin azalmasina sebep olabilir (Akbulut, 2006, s. 3).

"Uygulamalı öğrenme-öğretme yaşantılarını kapsayan çalgı dersleri, iletişimin birçok ögesini içinde barındıran hassas süreçlerden oluşmaktadır” (Zhukov, 2012, s. 467). Bu nedenle öğretmenler; sadece bilgi aktarımı konuşmalarıyla kısıtlı kalmayıp, iletişım öğelerini etkin kullanımıyla, öğrenci motivasyonuna olumlu etkiler sağlamaya çaba göstermelidir. Zira bu konudaki tavır ve çabalarına ilişkin öğrenci algıları önemsenmektedir (Turhal ve diğerleri 2018, s. 44). Öğrenme ortamında öğrencinin yüksek motivasyonunun öğrenmeyi olumlu etkilediği, düşük motivasyonunun olumsuz etkilediği varsayılan etkenlerin başarısızlığa neden olduğu bilinmektedir (Atay, 2004, s. 99). Öğrenciyle gerçekleştirilen müzikal çalışmalarda etkili biçimde alıştırma yapmanın prensipleri hakkında sohbetler önemlidir. Çalışmanın amacını ve gerekli yöntemi bilmeden yapılan çalışlar uzun ve monoton olabilmektedir (Ercan, 1999, s. 10). Burada çalgı öğretmenine önemli roller düşmektedir. Çünkü öğretmen özelliklerinin öğrenci motivasyonunda etkili olabildiği (Adamou, 2018; Cheon, Reeve ve Vansteenkiste, 2020; Cruikshank, Jenkins, ve Metcalf, 2009; Frenzel, Taxer, ve Schwab, 2019; Madriaga ve Arriaga, 2011; Orhan Özen, 2017; Reeve ve Jang, 2006; Sakız, 2016; Sürücü ve Ünal, 2018) bilinmektedir.

Müzik eğitimi literatürü dahilinde öğrenci motivasyonu ile ilgili olan ve mevcut çalışmayla bir yönüyle ilişkisi bulunduğu düşünülen güncel araştırmalar (Akın, 2019; Ekici, 2017, Girgin, 2015; Karaçoban, 2019; Lehimler ve Karataş, 2020; Kurtuldu ve Aksu, 2015; Madriaga ve Arriaga, 2011; Miksza, ve diğerleri, 2019; Modiri, 2012; Onuk, 2007; Orhan, 2006; Özevin 2006; Özevin ve Bilen, 2011; Özçelik Herdem, 2016; Özmenteş, 2013; Sarıçiftçi ve Köse, 2017; Sungurtekin, 2010; Şeker, 2017; Tabaru ve Şen; 2019; Ülker, 2019) müzik bağlamlı motivasyon ölçeği geliştirme, mesleki müzik eğitimi almakta olan öğrencilerin çeşitli derslere veya mesleğe motivasyonları ya da öğrencinin öğretmenden beklentisi gibi konular üzerinedir.

Öğrenci başarısında rol oynadığı bilinen motivasyonun düzeyi; araştırmalarda belirlenirken, yapılan araştırmaların çalışma gruplarına göre değişim gösterebileceğinden, öğrencilerin algılarına yönelik çalışmalara da ihtiyaç 
duyulmaktadır. Zira Gülbahar (2018, s. 584) öğrenme motivasyonu çerçevesinde nicel çalışmaların olduğunu ancak nitel çalışmaların nispeten az sayıda olduğunu vurgulamıştır.

Bu çalışmada, lisans düzeyinde çalgı eğitimi almakta olan öğrencilerden çalgı çalışma motivasyonlarını olumlu ve olumsuz etkileyen öğretmen özelliklerinin betimlemeleri istenmiş, elde edilen nitel verilerin değerlendirilmek istenmiştir. Bu amaçla; "öğrencilerin algılarına göre çalgı çalışma motivasyonlarını etkileyen öğretmen özellikleri nelerdir?” sorusu problem olarak belirlenmiştir.

Genel bağlamda bu tip çalışmaların sarmal olarak pratik katkısının olduğu düşünülmektedir. Çalışma bulgularının değerlendirilmesiyle çalgı öğretmeninin motivasyon bileşenlerine ilişkin farkındalığı artabilir.

\section{Yöntem}

\subsection{Araştırmanın Modeli}

Araştırma nitel betimsel tarama modelindedir. Lambert ve Lambert'e (2012, s. 255) göre nitel betimleme araştırmalarının temel amacı herhangi bir olgunun doğrudan ve basit bir betimlemesini sunmaktır. Nitel veriler, bireylerin olgu veya olaylara ilişkin algılarına dair bilgilerdir. Bu bilgiler belli amaçlar doğrultusunda, doğal ortamda, gözlem ve görüşme gibi çeşitli teknikler yoluyla elde edilebilir (Onwuegbuzie ve Leech, 2007, s. 5).

$\mathrm{Bu}$ çalışma öncesinde, G Power analizi ile; iki ortalama arasındaki ilişki temel alınarak ideal katılımcı sayısı hesaplaması yapılmıştır. Analize göre; bu araştırma için gerekli katılımcı sayısı 134 kişi olarak belirlenmiştir. Araştırma için; ulaşım ve uygulama kolaylığı nedeniyle tercih edilen Tokat Gaziosmanpaşa Üniversitesi Güzel Sanatlar Eğitimi Bölümü Müzik Eğitimi Anabilim Dalı Tüm lisans öğrencileri ve Niğde Ömer Halis Demir Üniversitesi Güzel Sanatlar Eğitimi Bölümü Müzik Eğitimi Anabilim Dalı Tüm lisans öğrencilerinin tamamı çalışma grubunu oluşturmuştur $(\mathrm{N}=240)$ Çalışma, çalışmaya gönüllü olduğunu ibraz ederek araştırma sorularına yönelik yazılı görüş beyan eden 172 öğrenci ile yürütülmüştür. Veriler, yapılandırılmış açık uçlu sorulardan oluşan form ile elde edilmiştir. Bu sorular araştırmacılar tarafından oluşturulan üç sorudan oluşmaktadır.

Katılımcıların \%50 (86)'si Tokat Gaziosmanpaşa Üniversitesi diğer \%50 (86)'si ise Niğde Ömer Halis Demir Üniversitesi'nde öğrencidir. \%60,1'i (104) kadın, \%39,9 (68)'u erkektir. Yaş aralıkları incelendiğinde 18-22 yaş arası \%81,7 (141) öğrenci, 23-27 yaş arası \%14,8 (25) öğrenci, 28 yaş ve üstü ise \%3,5 (6) öğrenci mevcuttur. Çalgılarına göre; \%24,9 (28)'u keman, \%21,4 (37) 'ü yan flüt, \%16,6 (28)'ü bağlama, \%9,8 (17)'i viyolonsel, $\% 9,3(16)$ 'si viyola, \%8,9 (15)'si gitar, \%4,6 (8)'s1 ud, \%2,9 (5)'u şan ve \%1,7(3)'si piyano öğrenmektedir. Katılımcıların \%36,5(63)'ü 1. sınıf, \%13,4(23)'ü 2. sınıf, \%27,5 (47)'si 3.sınıf, \%22,5 (39)'i 4. sinıf öğrencidir. Çalgıları çalma süreleri olarak; 1-4 yıl süreyle çalan \%45,6 (77) öğrenci, 5-8 yıl süreyle çalan \%50 (86) öğrenci, 9-12 yıl süreyle çalan \%4,4 (8) öğrenci bulunmaktadır.

\section{2. Çalışma Grubu}

2018-2019 eğitim-öğretim yılı Tokat Gaziosmanpaşa Üniversitesi Güzel Sanatlar Eğitimi Bölümü Müzik Eğitimi Anabilim Dalı Tüm lisans öğrencileri ve Niğde Ömer Halis Demir Üniversitesi Güzel Sanatlar Eğitimi Bölümü Müzik Eğitimi Anabilim Dalı Tüm lisans öğrencilerinin tamamı çalışma grubunu oluşturmuştur (N=240). Çalışma, çalışmaya gönüllü olduğunu ibraz ederek araştırma sorularına yönelik yazılı görüş beyan eden 172 öğrenci ile yürütülmüştür

\subsection{Verilerin Toplanması}

Araştırmanın yapılmasına Tokat Gaziosmanpaşa Üniversitesi Etik Kurulunca onay verilmiştir. Araştırmanın yürütülmesine ilişkin izin ise, ilgili Üniversite Rektörlüklerince sağlanmıştır. Ayrıca katılımcı öğrencilerden araştırmaya gönüllü olduklarına dair imzalı onay formu teslim alınmıştır. Görüşme soruları yazılı olarak sunulmuş, görüşler yazılı olarak alınmıştır. Kağıtlar öğrencilere araştırmacılar aracılığıyla dağıtılmış ve toplanmıştır.

\subsection{Verilerin Analizi}

Araştırmacılar araştırma sorularına göre temaları belirledikten sonra, oluşturulan çerçeveye göre verileri düzenlemişlerdir. Analizin geçerliği ve güvenirliği için doğrudan alıntılara yer verilmiş ve akran değerlendirmesinden yararlanılmıştır. Akran görüşleri ile Miles ve Huberman'ın (1994) formülü kullanılarak kodlayıcılar arası güvenirlik hesaplanmıştır. Miles ve Huberman'ın (1994) belirttiği gibi nitel çalışmalarda, uzman ve araştırmacı değerlendirmeleri arasındaki uyumun \%90 ve üzeri olduğu durumlarda güvenilirlik sağlanmış olmaktadır. Bu araştırmada \%95 oranında güvenirlik sağlanmıştır.

Yıldırım ve Şimşek (2013, s. 256)'in nitel betimsel yöntem için belirttiği işlem basamaklarına uygun şekilde araştırma sorularıyla anlamlı bir ilişki olduğu düşünülen katılımcı ifadeleri açıklanarak raporlanmıştır. Betimsel analizde, görüşülen ya da gözlenen bireylerin görüşlerini çarpıcı bir şekilde yansıtmak amacıyla doğrudan alıntılardan yararlanılmaktadır. Bilimsel etik nedeniyle doğrudan alıntı yapılan katılımcı öğrencilerin isimleri 
verilmemiş; her birine bir referans verilmiştir. Teyit imkânı sağlamak amacıyla, araştırma kapsamında toplanan veriler ve işlemler muhafaza edilmiştir.

\section{Bulgular}

Bu çalışmada, lisans düzeyinde çalgı eğitimi almakta olan öğrencilerden çalgı çalışma motivasyonlarını olumlu ve olumsuz etkileyen öğretmen özelliklerinin betimlemeleri istenmiş, bu bölümde ise elde edilen nitel verilere doğrudan alıntılarla örnekler verilmiştir.

Öğretmenlik özellikleri genel olarak; kişisel özellikler ve mesleki özellikler olarak iki boyutta ele alınmaktadır (Kavcar, 2002, s.1). Öğretmenlerin davranışları da bu özellikler temelinde gerçekleşmektedir. Bu nedenle mevcut çalışma bünyesinde belirlenen davranışlar kişisel ve mesleki özelliklere göre kategorize edilmiştir.

\subsection{Olumlu Öğretmen Özelliklerine İlișkin Temalar}

\subsection{1. Çalgı Öğretmeninin Olumlu Olarak Algılanan Kișisel Özellikleri}

Öğrenciler; çalgı öğretmenlerine ilişkin algıladıkları olumlu özellikleri belirtmişlerdir. Bunlardan kişisel özellikler kategorisinde yer alan temalar "enerjik, saygıll, ilgili, sabırlı, esprili” dir. Böylece öğrencilerin, çalgı çalışma motivasyonlarını olumlu etkilediğini düşündükleri kişisel öğretmen özellikleri beş temada toplanmıştır. Aşağıda her temaya birer örnek verilmiştir.

Enerjik- Ö90 “Onu sabah sabah bu kadar enerjik görünce çalışmadan gelmeye utanır insan, öğretmeni örnek alıp ben de daha fazla çalışmaya ve enerjili olmaya başladım.... başta uykumu düzenledim sonra da çalışma planı yapıp düzenli çalıştım"

Saygıl1-Ö133 “Çalgı öğretmenim bize saygı duyar. Herkesin eşit olduğunu, benim kimseden eksiğim olmadığını sıça vurgular. Böylece motivasyonum artar."

İlgili- Ö12 "Öğretmenimiz ilgili olduğu için çok şanslıyız. Ders içinde ve dışında her sorumuzu cevaplar."

Sabırl1-Ö37-“Derste çalamadığım zaman sabırlı davranarak benim motivasyonumu devam ettirir.”

Empati(anlayışlı)-Ö28“Öğretmenim beni anlıyor. Beni en çok çalgı çalışmaya bağlayan şey bu.”

Espirili- “...kızmak istese bile espiriyle söyler. Öyle olunca kırmadan dökmeden bizi uyarmış olur. Çalgımıza küstürmez."

\subsection{2. Çalgı Öğretmeninin Olumlu Olarak Algılanan Mesleki Özellikleri}

Öğrenciler; çalg1 öğretmenlerine ilişkin algıladıkları olumlu özellikleri belirtmişlerdir. Bunlardan mesleki özellikler kategorisinde yer alan temalar "hedef ve kazanımlar hakkında bilgilendirme yapması, iyi bir öğrenci olması, öğrencinin yeteneğini fark etmesini sağlaması, dönüt vermesi, kendini mesleki olarak yenilemesi, iyi müzisyen olması, kendi çalgı çalışma motivasyonunun yüksek olması, derse hazırlıklı gelmesi, destek vermesi, verdiği ödevi tanıtıp çözümletmesi, parça seçerken öğrencinin fikrini alması, iyi bir dinleyici olması, derste teorik bilgiye de yer vermesi, öğrenciyle birlikte çalması, çok nota kaynağının olması” olarak belirlenmiştir. Böylece öğrencilerin, çalgı çalışma motivasyonlarını olumlu etkilediğini düşündükleri mesleki öğretmen özellikleri 15 temada toplanmıştır. Aşağıda her temaya birer örnek verilmiştir.

Hedef ve kazanımlar hakkında bilgilendirme yapması-Ö136 "Ne yapmam gerektiğini ve bunu başardığımda neler olacağını söylediğinde çok iyi motive oluyorum.”

İyi bir öğrenci olmas1- Ö19 “Öğretmenim öğrenmeyi çok seviyor. Bana da öğrenmeyi öğretiyor. Bunlar beni heyecanlandırıyor. Sırf nota çalmak için değil, keşfetmek deneyimlemek için çalıyoruz. Önceden çalmadığı parçalar varsa benimle öğreniyor. İyi bir öğrenci olması beni de motive ediyor.”

Yeteneğimi fark etmemi sağlaması- Ö70 “Öğretmenim yeteneğimi fark etmemi sağladı. Yoksa bu çalgıyı yapamazdım."

Dönüt vermesi- Ö16 "Neleri doğru neleri yanlış yaptığımı söyler, ben de not alırım, sonra o notlara bakıp çok çalışmam gerektiğini düşünürüm.”

Kendini mesleki olarak yenilemesi- Ö15 "Kendini mesleki bakımdan sürekli günceller. Yeni şeyler okur, dinler benimle de paylaşır."

İyi müzisyen olması- Ö161 "O böyle güzel çaldıkça biz de gaza geliyoruz."

Kendi çalgı çalışma motivasyonunun yüksek olması - Ö94 "Bakıyorum dersi yoksa kendi çalışıyor. Bizim haydi haydi çalışmamız lazım diyoruz arkadaşlarla." 
Derse hazırlıklı gelmesi- Ö99 "Bazen ben bile ödevimi unuturken hoca benim çalacağım şeyle ilgili materyaller, farklı edisyonlar, videolar bulmuş gelmiş, utanıp çalışmaya başlarım.”

Destek vermesi-Ö150 "Hatalarım olunca bile gülümseyip benim yapabileceğimi düşünmesi beni motive eder. Yanlış çaldığımda gayet tatlı bir hitapla başarabileceğimi söyler."

Verdiği ödevi tanıtıp çözümletmesi- Ö21 "Bazı hocalar ödev verip çalış gel der. Ben şanslıyım. İlk ödevi verdiğinde hepsini çalar. Verdiği ödevi tanıtıp nasıl çözümleyeceğimi söyler. Çalışmayı öğretir.”

Parça seçerken fikrimi alması-Ö135 "Özel olarak seviyeme ya da beğenime uygun seçmek için parça seçerken fikrimi alarak melodik eserler vermesi daha istekle çalışmamı sağlıyor."

İyi bir dinleyici olması- "Çalgı öğretmenim iyi bir dinleyicidir. Sorularımı dinleyip cevaplar. Çalarken de aynı şekilde dikkatle dinler. Böyle olunca çalışma isteğim artar."

Derste teorik bilgiye de yer vermesi- "İşitme armoni gibi derslerde öğrendiklerimiz bu derste çalg1 öğretmenim sayesinde yerini buluyor. Eser veya etüdü analiz edebilirsem daha kolay çözüp çalışmaya motive olabiliyorum."

Benimle birlikte çalması Ö33 "Çalgı öğretmenim ders içerisinde ben çalarken eşlik ederek dersi daha aktif işlememizi sağllyor. Bu beni motive ediyor."

Çok nota kaynağının olması-Ö28 "Fazla nota kaynağ1 olduğu için çok yönlü ve çeşitli çalışıyorum. Çok eser ve etüt tanımış oluyorum.'

\subsection{Olumsuz Öğretmen Özelliklerine İlișkin Temalar}

\subsection{1. Çalgı Öğretmeninin Olumsuz Olarak Algılanan Kişisel Özellikleri}

Öğrenciler; çalg1 öğretmenlerine ilişkin algıladıkları olumsuz özellikleri belirtmişlerdir. Bunlardan kişisel özellikler kategorisinde yer alan temalar "Soğuk davranışları, kendi olumsuz duygu ve durumlarını öğrenciye yansıtması, ilgisizliği, öğrenci hata yaptığında aşağılaması/küçümsemesi”dir. Böylece öğrencilerin, çalgı çalışma motivasyonlarını olumsuz etkilediğini düşündükleri kişisel öğretmen özellikleri dört temada toplanmıştır. Aşağıda her temaya birer örnek verilmiştir.

Soğuk davranışları- Ö170 "Bazen çok soğuk davranıyor. O zaman içimden hiç çalgı çalmak gelmiyor."

Kendi olumsuz duygu ve durumlarını bana yansıtması-Ö78“Bazen halsiz veya yorgun olur. Bu zamanlarda bana çok aksettirir. Motivasyonum düşer.”

İlgisizliği- Ö35“'Sıkılmış gibi davranıyor. Bir an önce ders bitsin de çıkıp gideyim halleri var.”

Hata yaptığımda aşağılaması/küçümsemesi- Ö165 "Yanlış çaldığımda sanki bu bölüme hiç gelmemeliymişim gibi hissettirmesi beni olumsuz etkiliyor."

\subsection{2. Çalgı Öğretmeninin Olumsuz Olarak Algılanan Mesleki Özellikleri}

Öğrenciler; çalg1 öğretmenlerine ilişkin algıladıkları olumlu özellikleri belirtmişlerdir. Bunlardan mesleki özellikler kategorisinde yer alan temalar "çok ödev vermesi, düzeyin altında ya da üstünde ödev vermesi, çalınamayan yerleri anlatmak yerine yeni ödev vermesi, dersi aksatması, dersi uzatması"olarak belirlenmiştir. Böylece öğrencilerin, çalgı çalışma motivasyonlarını olumlu etkilediğini düşündükleri mesleki öğretmen özellikleri beş temada toplanmıştır. Aşağıda her temaya birer örnek verilmiştir.

Çok ödev vermesi- Ö114 "Beni kamçıladığını zannedip bir sürü ödev verdiğinde yapamayacağımı düşünüp hiç çalışmiyorum."

Düzeyin altında ya da üstünde ödev vermesi- Ö188 "Niye bu kadar zorluyor bilmiyorum ama öyle olunca çalışma motivasyonum düşüyor aslında.", Ö100 "Basit şeyler verince ben çalamıyorum herhâlde beğenmiyor seviyemi diyorum."

Çalınamayan yerleri anlatmak yerine yeni ödev vermesi- Ö107 "Yanlışlarımızı gösterse iyi olacak. Bunu yapmadığı için kötü etkiliyor. Ne olduğunu anlamadan yeni ödev geliyor."

Dersi aksatması-Ö145" Dersin başlama saatinde hocanın geç gelip benim bir saat önce orda olmama rağmen azar yemem nedeniyle ders gergin geçiyor."

Dersi uzatmas1- Ö165 "Ders bitiyor. Hoca dalıyor. Diğer derse zor yetişiyorum. Bu iyi değil. Dersin saatini öğreteceği konuya göre ayarlayabilir oysa." 


\section{3. Öğrencilerin Çalgı Öğretmeninden Beklentilerine İlişkin Temalar}

\subsection{1. Çalgı Öğretmeninin Kişisel Özelliklerine İlişkin Öğrenci Beklentileri}

Öğrenciler çalgı çalışma motivasyonlarına olumlu etki edeceğini düşündükleri için çalgı öğretmenlerinden bazı beklentilere sahiptir.

Bunlardan kişisel özellikler kapsamında değerlendirilen temalar "insani değerlere sahip olmak, yapıcı eleştirilerde bulunmak, anlayışlı olmak," olarak belirlenmiştir. Böylece öğrencilerin öğretmende olmasını istediklerini belirttikleri motivasyonel kişisel özellikler üç temada toplanmıştır. Aşağıda her temaya birer örnek verilmiştir.

Anlayışlı olmak-Ö99 “Öğrenciyi anlamaya çalışmalarını, empati yapmalarını beklerim.”

İnsani değerlere sahip olmak- Ö110 "Her şeyden önce insanız. Bunu hatırlasak yeter. Tavırlar bir anda motivasyonu başlatabilir ya da bitirebilir. Öğretmenin tavırları insani değerler çerçevesinde olursa öğrenci çalışır. Öğretmen öğrenciden çok şey bilebilir ama daha üstün değildir."

Yapıcı eleştirilerde bulunmak- Ö95 "Çalgı öğretmenlerinin yapıcı eleştirilerde bulunmasını isterim. Elimizde olmadan hatalı çalabiliyoruz. Heyecan falan olabiliyor."

\subsection{2. Çalgı Öğretmeninin Mesleki Özelliklerine İlişkin Öğrenci Beklentileri}

Öğrenciler çalgı çalışma motivasyonlarına olumlu etki edebileceğini düşündükleri için, çalgı öğretmenlerinden bazı beklentilere sahiptir. Bunlardan mesleki özellikler kapsamında değerlendirilen temalar "öğrenciyle birlikte çalmak, öğrencinin düzeyini bilmek, etkili çalma becerisine sahip olmak, ayrıntılı çalıştırmak; dinleti düzenlemek; kendini yenilemek" olarak belirlenmiştir. Böylece öğrencilerin öğretmende olmasını istediklerini belirttikleri motivasyonel mesleki özellikler altı temada toplanmıştır. Aşağıda her temaya birer örnek verilmiştir.

Öğrenciyle birlikte çalmak- Ö 157 “Çalgı öğretmeni öğrencisiyle birlikte çalarsa öğrenci daha doğru sesler çıkarıp motive olur bence."

Öğrencinin düzeyini bilmek-Ö135 "Kesinlikle öğrencinin düzeyini bilmeli, düzeyine göre başlayıp çok çalışması için motive etmeli, yoksa geri kalmış diye hızla ilerletmeye çalışmamalıdır."

Etkili çalma becerisine sahip olmak- Ö107 "Bence denetimle hocaların kontrol edilmesi gerekli. Yeterli değillerse yeterli seviyeye getirilmesi gerek. Onların bize çalması bizi motive etmeli, soğutmamalı."

Ayrıntılı çalıştırmak- Ö111 "Etütlere bolca yer verip, etüt çalışmaları iyice pekiştikten sonra vermiş olduğu eseri önce ölçü ölçü çalıştırmayı sonra da eser üzerindeki nüansları falan çalıştırmasını beklerdim.”

Dinleti düzenlemek -Ö41 "Motivasyon açısından düşünüyorsak, bir öğrenci hocasıyla konser verse tam motivasyon olur. Canla başla çalışır. Böyle şeyler düşünülebilir."

Kendini yenilemek- Ö140 "Özellikle çalgı öğretmeni kendini yenilemeli, hayatı boyunca aynı metodu çaldırırsan olmaz."

Bunların yanı sıra "Bana nasıl davranılıyorsa ben de öğretmen olunca aynısını uygulayacağım." ifadesi ek cümle olarak belirtilmiştir (Ö118, Ö134, Ö86, Ö78, Ö129, Ö130, Ö134, Ö2, Ö29, Ö55, Ö35, Ö162).

\section{Sonuç}

Normal şartlarda, bir öğrenci zamanının çoğunu okulda geçirmektedir. Öğrenci, ders süresince öğretmeninin davranışlarına dikkat etmekte ve yaklaşımlarından etkilenebilmektedir. Öğretmenin öğrenciye olan yaklaşımı, tavrı, konuşmaları, ses tonu, mimikleri ve bakışları öğrencinin motivasyonuna, motivasyonu da genel performansına ve diğer derslerine etki edebilir. Öğretmen öğrenciyle konuşurken; konuşma tarzı, cümleyi söyleme biçimi, bakışları, ses tonlaması ve mimiklerinden öğrenci olumsuz anlamlar çıkarabilir ve bu durum motivasyonunda düşüş sağlayabilir (Turhal ve diğerleri, 2008, s. 4). Bütün bunlar sonucunda motivasyonu düşük olan öğrencinin başarı düzeyi istenilen seviyeye erişemeyebilir (Akbaba, 2006, s. 344).

$\mathrm{Bu}$ çalışmada lisans düzeyinde çalgı eğitimi almakta olan öğrencilerin algılarına göre çalgı çalışma motivasyonlarını etkileyen öğretmen özellikleri belirlenmiştir. Mevcut çalışma; literatürde öğretmen özelliklerinin iki boyutta incelenmesi (Kavcar, 2002, s. 1) temel alınarak, iki kategori altında temalanmıştır. Buna göre sonuçlar; 1. öğretmenin olumlu motivasyonel kişisel özellikleri, 2. öğretmenin olumlu motivasyonel mesleki özellikleri 3. öğretmenin olumsuz motivasyonel kişisel özellikleri, 4. öğretmenin olumsuz motivasyonel mesleki özellikleri olarak kesimlenip, 5. ve 6. sonuç maddelerinde öneri bağlamında öğrencilerin öğretmenlerden motivasyonel beklentilerinin kişisel ve mesleki olarak kategorize edilen özelliklerle betimlenmesi yapılmıştır.

Öğrencilerin, çalgı öğretmenlerine ilişkin algıladıkları olumlu özellikler "enerjik, saygılı, ilgili, sabırlı ve esprili olmalarıdır. $\mathrm{Bu}$ beş özellik öğrencilerin ifadelerinden elde edilmiş, öğrencilerin öğretmenlerine atfettikleri 
motivasyonel olumlu kişisel özelliklerdir. Diğer bir değişle; öğrenciler, öğretmenlerinin bu özelliklerinin çalg1 çalışma motivasyonlarını olumlu etkilediğini düşünmektedir. Bu bakımdan belirtilen özelliklerin, katılımcıların çalgı öğretmenlerinde bulunduğu ve motivasyonel olarak işlevli olarak algılandığı anlaşılmaktadır.

Barışeri Ahmethan ve Yiğit (2018, s. 216) sevecen, destekçi, yetenekleri ortaya çıkaran, kendi motivasyonu yüksek, adaletli olması gereği vurgulanmıştır. Benzer şekilde Klem ve Connell, (2004, s. 3) öğrencilerin öğretmenlerini şefkatli, adil bir öğretmen olarak algıladıklarında okula daha fazla ilgi duyduklarını bildirmiştir.

Öğrenciler; çalgı öğretmenlerine ilişkin algıladıkları olumlu mesleki özellikler olarak "hedef ve kazanımlar hakkında bilgilendirme yapması, iyi bir öğrenci olması, öğrencinin yeteneğini fark etmesini sağlaması, dönüt vermesi, kendini mesleki olarak yenilemesi, iyi müzisyen olması, kendi çalgı çalışma motivasyonunun yüksek olması, derse hazırlıklı gelmesi, destek vermesi, verdiği ödevi tanıtıp çözümletmesi, parça seçerken öğrencinin fikrini alması, iyi bir dinleyici olması, derste teorik bilgiye de yer vermesi, öğrenciyle birlikte çalması, çok nota kaynağının olmasını belirtmiştir. Bu 15 tema, öğrencilerin öğretmenlerinde bulunduklarını ifade ettikleri olumlu motivasyonel özelliklerdir. Orhan (2006, s. 134) ve Sungurtekin (2010, s. 32) çalgı dersinde öğrenciyle birlikte çalmanın motivasyona olumlu etki ettiğini bildiren önceki yayınlardandır. Bunun dışında Özmenteş (2013, s. 327)'in çalgı eğitiminde hedef ve motivasyon ilişkisine dikkat çektiği görülmüştür. Hedefin belirlenmesi, yakın veya uzak olarak algılanması öğrencinin motivasyon düzeyini etkileyebilir. Bu çalışmada da çalgı programının öğrencinin neleri başarmasını beklediğinin öğretmen tarafından tanımlanmasının öğrencilerin motivasyonunu yükselttiği anlaşılmaktadır. Bulgulardan hareketle; bu hedefler doğrultusunda belirlenen ödevler ve ödevlerin ayrıntılı tanıtılması da öğrenciler tarafından önemli bulunmaktadır. Hatta ödev olarak verilen etüt ve eserlerin seçiminde öğrencinin tercihinin öğretmen tarafinda değerlendirilmesi, öğrencileri çalışmaya yönlendiren bir davranıştır. Zira Özmenteş (2013, s. 321), öğrencilerin repertuvara ilişkin tutumunun motivasyonel bağlamda öneminden bahseder. Tutumun yönünün motivasyon eğilimiyle ilişkili olduğu görülmektedir. Dolayısıyla öğrencinin tercihinin mümkün olduğunca değerlendirilmesinde fayda vardır. Bu konuda çalgı öğretmenleri farklı yaklaşımlar benimseyebilmektedirler. Ancak karara katılmasına firsat verilen öğrencinin, çalışmanın da sorumluluğunu alacağı düşünülmektedir. Literatüre göre; öğretmenlerin özerk destekleyici veya kontrol edici olma dereceleri, öğrencilerin içsel motivasyon ve kararlılıklarını önemli ölçüde etkiler (Pelletier ve diğerleri, 2002, s. 194; Radel, Sarrazin, Legrain ve Wild, 2010, s. 583). Müzikte oldukça yaygın bir öğrenme öğretmen yöntemi olarak bilinen usta çırak ilişkisi (Jørgensen, 2000, s. 76) zaman içinde otoriter tarzı getirmiş olabilir. Ancak öğretmenler çalmaya ilişkin her tür deneyimin sunulduğu özerk stili tercih edebilir (Niemiec ve Ryan, 2009, s. 140) Özerklik elde eden bireylerin daha motive olduğu bilinmektedir (Evans, 2015, s. 70; Reeve, 2009, s. 210).

Öğretmenin kendi motivasyonunun yüksek olmas1; öğrenme ve öğretmeye ilişkin tutumundan kaynaklanabilmektedir. İyi bir dinleyici olması, öğrenciye değerli olduğunu hissettirmektedir. Öğretmenin; öğrencisinin düzeyinin, potansiyelinin, hedefinin farkında olması, ona destek verebilmesi için ilk adımdır.

Ayrıca öğrenciler; öğretmenlerin soğuk davranışlarnını, kendi olumsuz duygu ve durumlarını öğrencilere yansıtmalarının, ilgisizliğinin, öğrenci hatalı çaldığında aşağılaması veya küçümsemesi gibi durumların, çalgı çalışma motivasyonlarına olumsuz etki ettiğini bildirmiş̧lerdir. Öğrencinin hata yapması durumunda aşağılanması özgüvenini etkileyerek başarısızlık hissi yaşamasına neden olabilir. Bu durum katılımcıların bildirdikleri gibi motivasyon düzeyini düşürebilmektedir. Bulgu, Özmenteş (2013, s. 326)'in çalışmasıyla örtüşmektedir. Barışeri Ahmethan ve Yiğit (2018, s. 216) de sevecen yaklaşmanın istendik öğretmen özellikleri olduğunu belirtmiştir. Cooper'e (2002) göre öğrencileriyle empati kuramayan öğretmenler, öğrencilerin duygularını, bireysel farklılıklarını önemsemeyerek sadece konuya ve programa yoğunlaşarak onların motivasyonlarının kaybolmasına neden olabilmektedir. Anderman ve diğerleri (1999, s. 132) ve Özmenteş (2013, s. 321), farklılıkların olumlu yönde kullanılmasının başarı üzerinde de etkili olacağını belirtmişlerdir.

Öğrenciler; çalgı öğretmenlerine ilişkin algıladıkları olumsuz mesleki özellikler olarak “çok ödev vermesi, düzeyin altında ya da üstünde ödev vermesi, çalınamayan yerleri anlatmak yerine yeni ödev vermesi, dersi aksatması, dersi uzatması" durumlarını bildirmişlerdir. Öğrenci ifadelerinden hareketle oluşturulan bu temalar incelendiğinde, öğrenci motivasyonunu olumsuz etkilediği bildirilen durumların genellikle ödev verme ve dersteki zaman yönetimi tabanlı olduğu anlaşılmaktadır. Öğretmenin düzeye uygun etüt ve eser vermesi önemlidir. Öğrenci potansiyelini keşfetmek ve ilerlemesini sağlamak için düzeyin biraz üstünde ödev verilmesi de bir yöntemdir. Ancak alt yapısı olmadan çok ileri düzey etüt veya eser verilmesi, motivasyonu düşürebilir. Çünkü burada hedef uzaktır. Bazı durumlarda ise beceriler, çalışma eksikliğinden gerileyebilmektedir. Bu durumda öğretmenler, verdikleri ödevin düzeyini bir adım geri çekebilirler. Bir öğretim basamağı başarılamadığında, onunla ilgili çalışmayı tekrarlamak, gerekirse bir adım geriden pratik etmek gerekebilir. Öğrenciler bu gerekçeleri çoğu zaman bilmediklerinden başka fikirlere kapılabilmektedirler. Dolayısıyla bunları açıklayarak ödev verilmesi yerinde olabilir. Çalışmada katılımcı öğrencilerin dönüt almadan sürekli yeni ödev aldığını belirtmesi ise istendik bir durum değildir. Bireysel çalgı dersinde zaman çok sınırlı olsa dahi eksikleri tamamlamak önemlidir. 
Destek verebilmesi için öğretmenin öğrenciyi tanıması ve iyi bir iletişim kurması gereklidir (Özmenteş, 2013, s. 326; Robinson, 2017; Sürücü ve Ünal, 2018, s. 265). Mevcut çalışmanın bulgularına göre; öğrencilerin çalg1 öğretmenlerinden motivasyonel bazı beklentilere sahip olduğu anlaşılmıştır. Bu beklentiler, kişisel öğretmen özellikleri kapsamında; öğretmenin insani değerlere sahip olması, yapıcı eleştirilerde bulunması ve anlayışlı olmasıdır. Mesleki özelliklerine ilişkin öğrenci beklentileri ise; çalgı öğretmeninin öğrenciyle birlikte çalması, öğrencinin düzeyini bilmesi, etkili çalma becerilerine sahip olması, ayrıntılı çalıştırması; dinletiler düzenlemesi ve kendini yenilemesidir. Benzer beklentiler Lehimler ve Karataş (2020, s. 359)'ın çalışmasında da bulgulanmıştır.

Öğretmen olmak için eğitim almakta olan öğrencilerin, öğretimin nasıl yapılması gerektiği konusunda öğrenci olarak deneyimlerine dayanan, öğretmenlerin öğretildikleri gibi öğretme eğiliminde olduklarına ilişkin önyargıları vardır (Fung ve Chow, 2002). Bu çalışmada da öğrenciler öğretmenlerini rol model aldıklarını belirtmişlerdir. Diğer bir değişle, öğretmenler öğrencilerine olumlu veya olumsuz olarak nasıl davranırlarsa, öğrenciler de bu yaşantılarını öğretmenliklerinde deneyimlemeyi planlamaktadır. Bu düşünce, çalışmada bulgulanmıştır ve öğretmenlere önemli bir sorumluluk yüklemektedir.

\section{Kaynakça}

Adamou, S. (2018). The influence of social support and basic psychological needs satisfaction on student academic motivation at a Cameroonian University: Structural equation modeling dissertations (Doctor of Philosophy dissertation, Andrews University, Michigan). Erişim adresi: https://digitalcommons.andrews.edu/ dissertations/1677

Akbaba, S. (2006). Eğitimde motivasyon. Kazım Karabekir Ĕ̆itim Fakültesi Dergisi, 13, 343-361. Erişim adresi: https://dergipark.org.tr/tr/pub/ataunikkefd/issue/2774/37170

Akbulut, E. (2006). Günümüz müzik eğitimcisi nasıl olmalıdır?. Pamukkale Üniversitesi Eğitim Fakültesi Dergisi, 20, 23-28. Erişim adresi: https://dergipark.org.tr/tr/pub/pauefd/issue/11123/133023

Akın, O. N. (2019). Güzel sanatlar liseleri müzik bölümlerinde çalgı eğitimi viyola dersinde motivasyonun önemine ilişkin öğretmen ve öğrenci görüşlerinin değerlendirilmesi (Yüksek lisans tezi). YÖK Tez veri tabanından erişildi (Tez No. 567713).

Amrai, K., Motlagh, S., Zalani, H., \& Parhon, H. (2011). The relationship between academic motivation and academic achievement students. Procedia Social and Behavioral, 15, 399-402. doi:10.1016/J.Sbspro.2011.03. 111

Anderman, E., Maehr, M., \& Midgley, C. (1999). Declining motivation after the transition to middle school: Schools can make a difference. Journal of Research and Development in Education, 32(3), 131-147. Erişim adresi: https://www.scirp.org/(S(351jmbntvnsjt1aadkposzje))/reference/ReferencesPapers.aspx?ReferenceID $=1963805$

Atay, D. (2004). İngilizce öğretmenlerinin motivasyon stratejileri. Hasan Ali Yücel Eğitim Fakültesi Dergisi, 1(1), 99-108. Erişim adresi: https://hayefjournal.org/Content/files/sayilar/108/108.pdf

Barışeri Ahmethan, N., \& Yiğit, V. B. (2018). Müzik öğretmen adaylarının ideal müzik öğretmeni algılarının incelenmesi. Mustafa Kemal Üniversitesi Sosyal Bilimler Enstitüsü Dergisi, 15(41), 202-225. Erişim adresi: https://dergipark.org.tr/tr/pub/mkusbed/issue/36823/315714

Caruth, G. (2018). Student engagement, retention, and motivation: Assessing academic success in today's college students. Participatory Educational Research, 5(1), 17-30. doi:10.17275/Per.18.4.5.1

Cheon, S. H., Reeve, J., \& Vansteenkiste, M. (2020). When teachers learn how to provide classroom structure in an autonomy-supportive way: Benefts to teachers and their students. Teaching and Teacher Education, 90. doi: https://doi.org/10.1016/j.tate.2019.103004.

Cooper, B. (2002). Teachers as moral models: the role of empathy in the relationships between teachers and their pupils (Doctotal thesis, Sunderland, University of Sunderland). Erişim adresi: http://sure.sunderland.ac.uk/id/ eprint/6869

Cruikshank, D., Jenkins, D., \& Metcalf, K. (2009). The act of teaching. Boston: McGraw-Hill Higher Education.

Dilekmen, M., \& Ada, Ş. (2005). Öğrenmede güdülenme. Kazım Karabekir Eğitim Fakültesi Dergisi, 11, 113 123.

Eggen, P., \& Kauchak, D. (2001). Educational psychology: Windows on classrooms. New Jersey: New Jersey Prentice Hall, Inc. 
Ekici, T. (2017). Bireysel ses eğitimi dersine yönelik motivasyon ölçeği geliştirme. Akademik Bakış Dergisi, 60, 1694-528. Erişim adresi: http://www.akademikbakis.org

Ercan, N. (1999). Bireysel çalgl ĕğtiminde öğretmen-öğrenci ilişkilerine çağdaş yaklaşımlar. Öğretmen Eğitiminde Çağdaş Yaklaşımlar Sempozyumunda sunulan bildiri, Dokuz Eylül Üniversitesi Buca Eğitim Fakültesi, İzmir. Erişim adresi: http://acikerisim.deu.edu.tr:8080/xmlui/handle/20.500.12397/762

Evans, P. (2015). Kendi kaderini tayin teorisi: Müzik eğitiminde motivasyona yaklaşım. Musicae Scientiae, 19, 65-83. doi: 10.1177 / 1029864914568044

Francis, A., Goheer, A., Haver-Dieter, R., Kaplan, A., Kerstetter, K., Kirk, A., \& Yeh, T. (2004). Promoting academic achievement and motivation: A discussion \& contemporary issues based approach. University of Maryland.

Frenzel, A., Taxer, J., \& Schwab, C. (2019). Independent and joint effects of teacher enthusiasm and motivation on student motivation and experiences: A field experiment. Motivation and Emotion, 43, 255-265.

Fung, L., \& Chow, L. P. Y. (2002). Congruence of student teachers' pedagogical images and actual classroom practices. Educational Research, 44, 313-321.

Gaunt, H. (2011). Understanding the one-to-one relationship in instrumental/vocal tuition in higher education: Comparing student and teacher perceptions. British Journal of Music Education, 28, 159-179. doi:10.1017/S0265051711000052

Girgin, D. (2015). Bireysel çalgı dersi motivasyon ölçeği: Geçerlik güvenirlik analizi. K. Ü. Kastamonu Ĕ̆itim Dergisi, 23(4), 1723-1736. Erişim adresi: https://dergipark.org.tr/tr/download/article-file/209803

Goodman, S., Thania, J., Mira, K., Fahrin, M., Dolly, M., Mazvita, M., Joao, P., \& Anton, S. (2011). An investigation of the relationship between students' motivation and academic performance as mediated by effort. South African Journal of Psychology, 41(3), 373-385.

Gorham, J., \& Millette, D. (1997). A comparative analysis of teacher and student perceptions of sources of motivation and demotivation in college classes. Communication Education, 46(4), 245-261. doi: $10.1080 / 03634529709379099$

Gülbahar, B. (2018). The factors which affect learning motivation of higher education. R. Efe (Ed.), Educational Science Research in the Globalizing World (s. 584-607) içinde. Sofia: St. Kliment Ohridski University Press.

Jørgensen, H. (2000). Student learning in higher instrumental education: who is responsible?. British Journal of Music Education, 17, 67-77. doi:10.1017/S0265051700000164

Karaçoban, İ. B. (2019). Güzel sanatlar ve eğitim fakülteleri müzik bölümündeki flüt öğrencilerinin çalgılarına yönelik motivasyon düzeylerinin incelenmesi (Yüksek lisans tezi). YÖK Tez veri tabanından erişildi (Tez No. 551174).

Kaufmann, D., \& Humsan, J. (2004). Effects of time perspective on student motivation: Introduction to a special 1ssue. Educational Psychology Review, 16(1), 1-7.

Kavcar, C. (2002). Cumhuriyet döneminde dal öğretmeni yetiştirme. Ankara Üniversitesi Eğitim Bilimleri Fakültesi Dergisi, 35(1-2), 1-14. Erişim adresi: https://dergipark.org.tr/download/article-file/509256

Klem, A., \& Cornell, J. (2004). Relationships matter: linking teacher support to student engagement and achievement. Journal of School Health, 74(7), 262-273. Erişim adresi: https://osse.dc.gov/sites/default/files/ dc/sites/osse/page_content/attachments/Klem_and_Connell_2004_JOSH_article.pdf

Kurtuldu, M., \& Aksu, C. (2015). Müzik öğretmeni adaylarının piyano dersi motivasyon düzeylerinin çeşitli değişkenler açısından incelenmesi. Academia Social Science Journal, 3(21), 321-329.

Lambert, V. A., \& Lambert, C. E. (2012). Qualitative descriptive research: An acceptable design. Pacific Rim International Journal of Nursing Research, 16, 255-256. Erişim adresi: https://he02.tci-thaijo.org/index.php/ PRIJNR/article/view/5805/5064

Lehimler, E., \& Karataş, K. O. (2020). Müzik öğretmenliği lisans programında yer alan piyano eğitimi dersine yönelik öğretim elemanı ve öğrenci beklentileri. Atatürk Üniversitesi Güzel Sanatlar Enstitüsü Dergisi, 26 (Müzik Özel Sayıs1), 353-365. doi: https://doi.org/10.35247/ataunigsed.661021

Madriaga, J., \& Arriaga, C. (2011). Analysis of the educational practice of music teachers and their relationship with student motivation. Cultura y Educación, 23(3), 463-476. 
Margolis, H., \& Mccabe, P. (2004). Self-Efficacy a key to improving the motivation of struggling learners. The Clearing House, 77(6), 241-249.

Maric, M., \& Sakac, M. (2014). Individual and Social factors related to students' academic achievement and motivation for learning. Suvremena Psihologija, 17, 63-79.

Maulana, R., Opdenakker, M. C., \& Bosker, R. (2016). Teachers' instructional behaviors as important predictors of academic motivation: Changes and links across the school year. Learning and Individual Differences, 50, 147-156. Erişim adresi: https://www.sciencedirect.com/science/article/pii/S1041608016301443?via\%3Dihub

McPherson, G. E., \& Renwick, J. M. (2011). Öz düzenleme ve müzik becerilerine hâkim olma. B. J. Zimmerman \& D. H. Schunk (Eds.), Öğrenme ve performansın kendi kendini düzenlemesine ilişkin el kitabı içinde. New York: Routledge.

Miksza, P., Evans, P., \& McPherson, G. E. (2019). Motivation to pursue a career in music: The role of social constraints in university music programs. Psychology of Music. doi: https://doi.org/10.1177/ 0305735619836269

Miles, M. B., \& Huberman, A. M. (1994). Qualitative data analysis: An expanded sourcebook. Thousand Oaks, CA: Sage.

Modiri, I. G. (2012). Müzik öğretmenliği öğrencilerinin piyano dersi motivasyonları ile kişilik özellikleri arasındaki ilişki. Van Yüzüncü Yıl Eğitim Fakültesi Dergisi, 9(1), 74-98.

Murphy, P., \& Alexender, P. (2000). A Motivated Exploration Of Motivation Terminology. Contemporary Educational Psychology, 25, 3-53.

Niemiec, C. P., \& Ryan, R. M. (2009). Autonomy, competence, and relatedness in the classroom: Applying selfdetermination theory to educational practice. Theory and Research in Education, 7, 133-144. doi: https://doi.org/10.1177/1477878509104318

Onuk, Ö. (2007). Müzik öğretmenliği lisans programı öğrencilerinin öğretmenliğe güdülenmeleri ile akademik başarıları arasındaki ilişki (Doktora Tezi). YÖK Tez veri tabanından erișildi (Tez No. 207114).

Onwuegbuzie, A. J., \& Leech, N. L. (2007). Sampling designs in qualitative research: Making the sampling process more public. The Qualitative Report, 12(2), 238-254. Erişim adresi: https://nsuworks.nova.edu/tqr/vol12/iss2/7

Opdenakker, M. C., Maulana, R., \& Den Brok, P. (2012). Teacher-student interpersonal relationships and academic motivation within one school year: Developmental changes and linkage. School Effectiveness and School Improvement, 23(1), 95-119. doi:10.1080/09243453.2011.619198

Orhan Özen, S. (2017). The effect of motivation on student achievement. E. Karadağ(Ed.), The factors effecting student achievement (s. 35-56) içinde. Cham, Switzerland: Springer International Publishing. doi: 10.1007/978-3-319-56083-0_3

Orhan, Ş. Y. (2006). Anadolu güzel sanatlar liseleri çalg1 eğitiminde motivasyon. Dokuz Eylül Üniversitesi Buca Ĕ̈itim Fakültesi Dergisi, 20, 130-136. Erişim adresi: https://dergipark.org.tr/tr/pub/deubefd/issue/25440/ 268429

Özçelik Herdem, D. (2016). Öğretim elemanı görüşlerine göre keman eğitiminde öğrencilerin motivasyonlarını artırmaya yönelik yaklaşımların değerlendirilmesi. Journal of Strategic Research in Social Science (JoSReSS), 2(4), 2459-0029.

Özevin Tokinan, B., \& Bilen, S. (2011). Yaratıcı dans etkinliklerinin motivasyon, özgüven, özyeterlik ve dans performansı üzerindeki etkileri. Hacettepe Üniversitesi Ĕ̆itim Fakültesi Dergisi, 40, 363-374.

Özevin, B. (2006). Oyun, dans ve müzik dersine ilişkin motivasyon ölçeği. Ulusal Müzik Eğitimi Sempozyumu'nda sunulan bildiri, Pamukkale Üniversitesi Eğitim Fakültesi, Denizli.

Özgüngör, S. (2006). Üniversite öğrencilerinin amaç tarzlarının ve öğretmenlerinin özerklik destekleyici davranışlarına ilişkin algılarının öğrenci motivasyonu ve akademik davranışlarıyla ilişkisi. Türk Psikolojik Danışma ve Rehberlik Dergisi, 3(25), 27-36. Erişim adresi: https://dergipark.org.tr/tr/pub/tpdrd/issue/21445/ 229858

Özgüngör, S., \& Kapıkıran, Ş. (2008). Güzel sanatlar eğitimi öğrencilerinin öğretmenlik meslek bilgisi derslerine ilişkin motivasyon ve başarı düzeyleri. Pamukkale Üniversitesi Ĕgitim Fakültesi Dergisi, 1(23), 47-60. 
Özmenteş, S. (2013). Çalgı eğitiminde öğrenci motivasyonu ve performans. Ĕ̆itim ve Öğretim Araştırmaları Dergisi, 2(2), 2146-9199. Erişim adresi: http://www.jret.org/FileUpload/ks281142/File/35._sabahat_ ozmentes.pdf

Passini, S., Molinari, L., \& Speltini, G. (2015). A validation of the questionnaire on teacher interaction in Italian secondary school students: The effect of positive relations on motivation and academic achievement. Social Psychology of Education, 18(3), 547-559. doi: 10.1007/s11218-015-9300-3

Pelletier, L. G., Séguin-Lévesque, C., \& Legault, L. (2002). Pressure from above and pressure from below as determinants of teachers' motivation and teaching behaviors. Journal of Educational Psychology, 94(1), 186196. doi: https://doi.org/10.1037/0022-0663.94.1.186

Pintrich, P. R., \& Schunk, D. (2002). Motivation in education: Theory, research, and applications (2nd ed). Upper Saddle River, NJ: Merril Prentice Hall. Erişim adresi: https://searchworks.stanford.edu/view/6774934

Radel, R., Sarrazin, P., Legrain, P., \& Wild, T. C. (2010). Social contagion of motivation between teacher and student: Analyzing underlying processes. Journal of Educational Psychology, 102(3), 577-587. doi: https://doi.org/10.1037/a0019051

Reeve, J. (2009). Öğretmenler neden öğrencilere karşı kontrol edici bir motive edici stil benimsiyorlar ve nasıl daha fazla özerklik destekleyici olabilirler. Ĕgitim Psikoloğu, 44, 159-175. doi: 10.1080 / 00461520903028990

Reeve, J., \& Jang, H. (2006). What teachers say and do to support students' autonomy during a learning activity. Journal of Educational Psychology, 98(1), 209-218. doi: https://doi.org/10.1037/0022-0663.98.1.209

Robinson, K. (2017). Yaratıcı öğrenciler: Çocukların geleceğini düşünenler için eğitimde yaratıcılık devrimi. (D. Boyraz, Çev.). İstanbul: Sola Yayınları.

Sakız, G. (2016). Etkili öğretmenlik ve öğretmen niteliğinin geliştirilmesi. Kuramsal Ĕgitimbilim Dergisi, 9(2), 214-244.

Sarıçiftçi, A. Ö., \& Köse, H. S. (2017). Koro dersi motivasyon ölçeği geliştirilmesi ve öğrencilerin motivasyon düzeylerinin karşılaștırılmalı olarak incelenmesi. Mehmet Akif Ersoy Üniversitesi Sosyal Bilimler Enstitüsü Dergisi, 9(22), 207-224.

Slavin, R. E. (2013). Öğrencileri öğrenmeye motive etmek. G. Yüksel (Ed. ve Çev.). Ankara: Nobel Yayınları.

Sungurtekin, M. (2010). Motivasyon ve çalg1 eğitimindeki yeri. e-Journal of New World Sciences Academy, 5(1), 28-34. Erişim adresi: https://dergipark.org.tr/en/download/article-file/186621

Sürücü, A., \& Ünal, A. (2018). Öğrenci motivasyonunu artıran ve azaltan öğretmen davranışlarının incelenmesi. OPUS-Uluslararası Toplum Araştırmaları Dergisi, 8(14), 253-295. doi: 10.26466/opus.404122

Şeker, S. S. (2017). Müzik eğitimi bölümü öğretmen adaylarının akademik güdülenme ve akademik öz-yeterlik düzeylerinin incelenmesi. Abant İzzet Baysal Üniversitesi Eğitim Fakültesi Dergisi, 17(3), 1465-1484.

Tabaru, A., \& Şen, Ü. (2019). Müzik öğretmeni adaylarının bireysel ses eğitimi dersine yönelik motivasyon düzeylerinin incelenmesi. Journal Of International Social Research, 12(66), 924-946.

Turhal, E., Kalyoncu, N., \& Keçeci, A. (2018). Çalgı derslerindeki öğretmen- öğrenci iletişiminde "transaksiyonel analiz ego durumları". Sanat ve Tasarım Dergisi, 8(2), 42-65. doi: https://doi.org/10.20488/sanattasarim. 529225

Umuzdaş, S. (2013). Viyolonsel sol el teknik çalışmaları. Ankara: Pegem Yayınları.

Ülker, A. (2019). Güzel sanatlar liselerinin müzik bölümlerinde flüt eğitimi alan öğrencilerin çalgılarına yönelik güdülenme düzeylerinin incelenmesi (Yüksek lisans tezi). YÖK Tez veri tabanından erişildi (Tez No. 562353).

Vallerand, R., \& Thill, E. (1993). Introduction a lapsychologie de la motivation. Laval, QC: E'tudes Vivantes.

Wang, M. T., \& Eccles, J. S. (2013). School context, achievementmotivation, and academic engagement: A longitudinal study of school engagement using a multidimensional perspective. Learning and Instruction, 28, 12-23. doi: http://dx.doi.org/10.1016/j.learninstruc.2013.04.002

Yazic1, H., \& Altun, F. (2013). The association between university students' internal and external motivation sources and their academic achievement. International Journal of Social Science, 6(6), 1241-1252.

Yıldırım A., \& Şimşek H. (2013). Sosyal bilimlerde nitel araştırma yöntemleri (9. Baskı). İstanbul: Seçkin Yayincilik. 
Young, V., Burwell, K., \& Pickup, D. (2003). Çalışma alanları ve öğretim stratejileri enstrümantal öğretim: Bir vaka çalışması araştırma projesi. Müzik Eğitimi Araştırması, 5, 139-155. doi: 10.1080/1461380032000085522

Zhukov, K. (2012). Interpersonal interactions in instrumental lessons: teacher/student verbal and non-verbal behaviours. Psychology of Music, 41(4), 466-483. doi: 10.1177/0305735611430434 